Металлофиз. новейшие технол. / Metallofiz. Noveishie Tekhnol. () 2015 ИМФ (Институт металлофизики 2015 , т. 37 , № 4, сс. 499-508

Оттиски доступны непосредственно от издателя

им. Г. В. Курдюмова НАН Украины)

Фотокопирование разрешено только

Напечатано в Украине.

в соответствии с лицензией

PACS numbers: 52.50.Dg, 52.50.Qt, 61.46.Bc, 68.35.Ct, 68.35.Dv, 81.16.Rf, 82.33.Xj

\title{
Formation of Nanostructured Relief of TiN-Fe Heterostructures in Hybrid Helicon-Arc Plasma Reactor
}

E. M. Rudenko, I. V. Korotash, D. Y. Polotskiy, L. S. Osipov, M. V. Dyakin, T. A. Prikhna*, and A. P. Shapovalov"

G. V. Kurdyumov Institute for Metal Physics, N.A.S. of Ukraine, 36 Academician Vernadsky Blvd., UA-03680 Kyiv, Ukraine

"V. Bakul Institute for Superhard Materials, N.A.S. of Ukraine, 2 Avtozavodska Str.,

04074 Kyiv, Ukraine

The features of the physical mechanisms of controlled ion-plasma formation of the new functional nanomaterials are investigated. The technological regimes of formation of functional nanostructured materials under combined impact of several plasma sources are investigated; the structural and electrical properties of the obtained TiN films are studied. The structures of films are studied with scanning tunnelling microscope JSPM-4500/4610 interlocked with an atomic force microscope. As shown, the optimized helicon-arc reactor demonstrates the unique properties and provides controlled lowtemperature formation of the dense regular TiN nanostructures with the sizes from a few to tens of nanometres.

Вивчено особливості фізичних механізмів керованого йонно-плазмового формування нових функціональних наноматеріялів. Відпрацьовано технологічні режими формування функціональних наноструктурованих матеріялів за спільної роботи кількох джерел плазми; вивчено структурні та електрофізичні особливості одержаних плівок TiN. Структури плівок досліджено на сканівному тунельному мікроскопі JSPM-4500/4610, зблокованому з атомним силовим мікроскопом. Встановлено, що оптимізований гелікон-дуговий реактор демонструє унікальні властивості і забезпечує кероване низькотемпературне формування щільних упорядкованих наноструктур TiN з розмірами від одиниць до десятків нанометрів.

Изучены особенности физических механизмов управляемого ионноплазменного формирования новых функциональных наноматериалов. Отработаны технологические режимы формирования функциональных наноструктурированных материалов при совместной работе нескольких источников плазмы; изучены структурные и электрофизические особен- 
ности полученных плёнок TiN. Структуры плёнок исследованы на сканирующем туннельном микроскопе JSPM-4500/4610, сблокированном с атомным силовым микроскопом. Установлено, что оптимизированный геликонно-дуговой реактор демонстрирует уникальные свойства и обеспечивает управляемое низкотемпературное формирование плотных упорядоченных наноструктур TiN с размерами от единиц до десятков нанометров.

Key words: TiN films, plasma, nanostructures, helicon-arc reactor.

(Received December 19, 2014)

\section{INTRODUCTION}

Nanoscale materials have unique physical, chemical, and biological properties that are significantly different from those at macro- and microscale. This allows us to develop new applications, for example, to create specific materials, devices, and functional systems.

Recently carbon nanotubes (CNTs) became of great interest. Prospects for application of CNTs and other carbon-based nanostructures in micro- and nanoelectronics are caused by peculiarities of their electronic properties as systems with reduced dimensionality, e.g., CNT is quasi-one-dimensional (quasi-1D) structure. The long-term implementation of the ballistic electron-transport regime in such systems could lead to ultralow levels of an electrical resistance. That is why CNTs could be one of the fundamental building blocks for nanoelectronics $[1,2]$.

It should be noted that for the date an activated plasma-enhanced chemical vapour deposition (PECVD) is the only deterministic CNT growth technology, which allows us to control a position, size, shape, and structure of CNTs at a certain extent and synthesize CNTs at lower temperatures [3-5]. Main technological operations in PECVD process to provide high-quality CNT synthesis are: 1) deposition of diffusion barrier sublayer; 2) formation of nanostructured films of metal catalyst; 3) synthesis of CNTs. Ni, Fe, Co, and their combinations are commonly used as catalysts [6]. However, if Si single-crystal is used as a substrate, then deposition of a passivation (protective) layer, for example, TiN, is necessary in order to prevent chemical interaction between Si substrate and a catalyst layer. In addition, a nanostructured relief must be formed at a catalytic layer, which provides creation of CNT with a regular structure for the needs of electronics. The possibility to create CNTs with a regular structure at nanostructured relief is demonstrated in investigations of CNT synthesis on the catalytic Fe layer formed on the single-crystal Si substrate [7].

The object of these investigations is a study of formation of nanostructured relief in $\mathrm{TiN}-\mathrm{Fe}$ heterostructure at $n$-Si(100) sub- 
strate. The solution of this problem can be helpful for creation of technological bases for the usage of CNTs for the needs of electronics.

\section{EXPERIMENTAL}

The new hybrid ion-plasma reactor based on helicon and magnetoactivated vacuum-arc (MAVA) sources (created in Institute for Metal Physics, N.A.S.U.) is used to develop the physical foundations of the new technology of synthesis of nanostructured materials [8]. The technological chamber (see Fig. 1) consists of the discharge chamber of the helicon source (with the diameter and the length of $20 \mathrm{~cm}$ ) and the drift chamber (with the diameter of $35 \mathrm{~cm}$ and the length of $25 \mathrm{~cm}$ ) docked to it. The discharge in argon, in reactive gases $\left(\mathrm{O}_{2}\right.$, and $\mathrm{C}_{2} \mathrm{Cl}_{2} \mathrm{H}_{4}, \mathrm{SiH}_{4}$ in gaseous states) under a pressure of 7-8 mTorr is excited by the planar antenna with the diameter of $11 \mathrm{~cm}$, which is plugged in by the interface unit to the RF (radio frequency) generator with the frequency of $13.56 \mathrm{MHz}$ and the power of $1 \mathrm{~kW}$. The magnetic system of the helicon plasma source consisted of two parts. The solenoid, which covers the discharge chamber and provides the discharge excitation and plasma generation in the right mode. The control magnetic system with the independent power supply allows us to adjust the magnetic field in the drift chamber with no significant change in its discharge chamber.

Two modules of MAVA sources are docked to the drift chamber that allowed us to deposit film heterostructures with different chemical

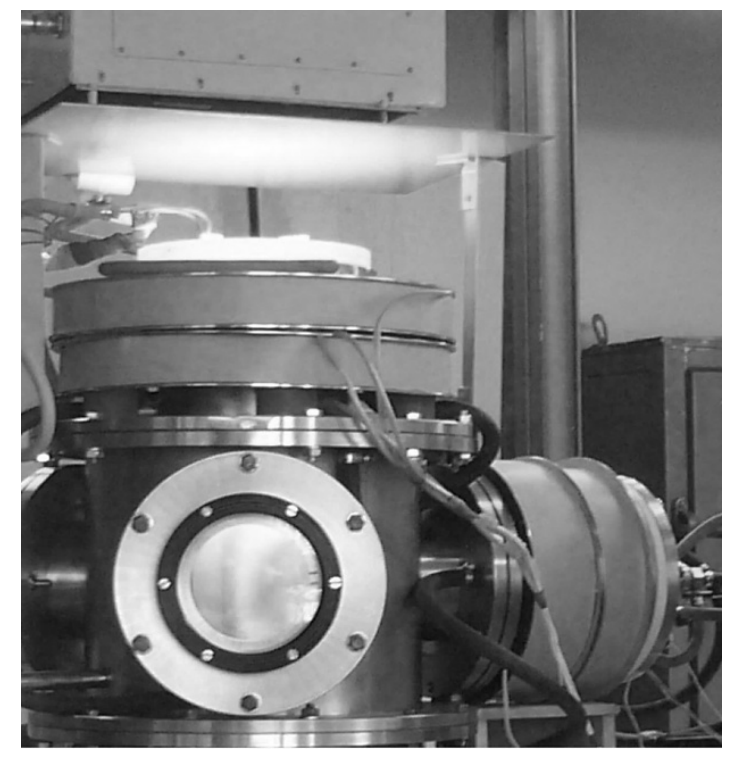

Fig. 1. The technology chamber with the helicon and plasma-arc sources. 
composition. Figure 1 shows the right MAVA reactor (the second MAVA reactor is located symmetrically leftward). The substrate holder is placed at the bottom of the drift chamber, where the electric potential in the range of $0-200 \mathrm{~V}$ is applied.

The reactor in the single vacuum cycle could carry out the following technological operations: 1) sample surface treatment by plasma of helicon sources at different potentials applied to the substrate in different working gaseous environments; 2) film deposition with using MAVA sources at different potentials applied to the substrate. For these investigations, the experimental samples of TiN-films on silicon substrates were obtained by the following technological scheme. The first stage consisted of clearing and activating the surface of the silicon substrate by the helicon source plasma (with RF power of $300 \mathrm{~W}$ ) in the argon atmosphere under the pressure of $2 \mathrm{~Pa}$ for 15-20 minutes until the electrode current in the substrate holder will not fall to $2.3 \mathrm{~mA}$. The second stage consisted of forming the TiN film layer by the cyclic procedure (10 cycles in total) at two different stages: 1$) \mathrm{TiN}$ film deposition by MAVA source with the titanium oxide cathode in the nitrogen atmosphere (under the pressure of $0.6 \mathrm{~Pa}$ and the arc current of $40 \mathrm{~A}$ ) during 20 seconds; 2) treatment by helicon plasma source (with RF power of $300 \mathrm{~W}$ ) in argon atmosphere under pressure of $1 \mathrm{~Pa}$ during 40 seconds. The potential at the substrate holder was a variable parameter. In addition to the above mentioned technological stages in formation of TiN-film layer, Fe-film deposition by MAVA source with the iron cathode in the argon atmosphere was carried out at the final stage for 30 seconds (under the pressure of $0.6 \mathrm{~Pa}$ and the arc current of $45 \mathrm{~A}$ ) to generate TiN-Fe heterostructures on Si substrates.

\section{RESULTS AND DISCUSSION}

The effect of technological conditions (related to formation of $\mathrm{Si}-\mathrm{TiN}$ film structures on Si substrates obtained in a hybrid helicon-arc reactor) on the surface morphology of the films is investigated by atomic force microscopy (AFM). The structural studies were targeted to optimize the formation regimes of nanostructured topography of the films. The results of the studies of a surface topography for the film structures obtained by various technological parameters are shown in Fig. 2-4: the surface topography of the film structures is shown at different magnifications in Fig. 2-4 ( $a$ and $b$ ), and the numerical calculations of the data are shown in Fig. 2-4 ( $c$ and $d$ ). In Figures 2-4, the surface roughness values $R_{\mathrm{pv}}$ and $R_{\mathrm{ms}}$ are given under the figures of the surface topography (Fig. $2-4, a$ and $b$ ). The latter parameter $\left(R_{\mathrm{ms}}\right)$ describes the standard deviation of height values for the surface relief. The essential feature of the formation regime of these film structures is the cyclic impact of the argon ion flow generated in the helicon plas- 
ma source of hybrid helicon-arc reactor. As known, the condensate formation on the substrate surface causes simultaneous adsorption, diffusion, desorption, and energy relaxation of surface atoms, and formation of atomic and chemical bonds. However, all these processes will be affected significantly by the density and the average ion energy of plasma flow along with the substrate temperature and flow density.

As one can see from Fig. 2, for the average ion energy in the flow about $90 \mathrm{eV}$, the dense nanostructured film structure is formed with the average crystallite size of $5-20 \mathrm{~nm}$ and the surface roughness parameters $R_{\mathrm{pv}}=48 \AA$ and $R_{\mathrm{ms}}=4.3 \AA$. Under these technological conditions, the formation process of a nanostructured surface relief in films probably occurs with a predominance of desorption over adsorption of atoms. The energy relaxation of surface ions goes to the level of the equilibrium temperature of a condensate against the background of intense surface energy disturbance and therefore this energy relaxation has negligible influence on formation of atomic and chemical bonds.
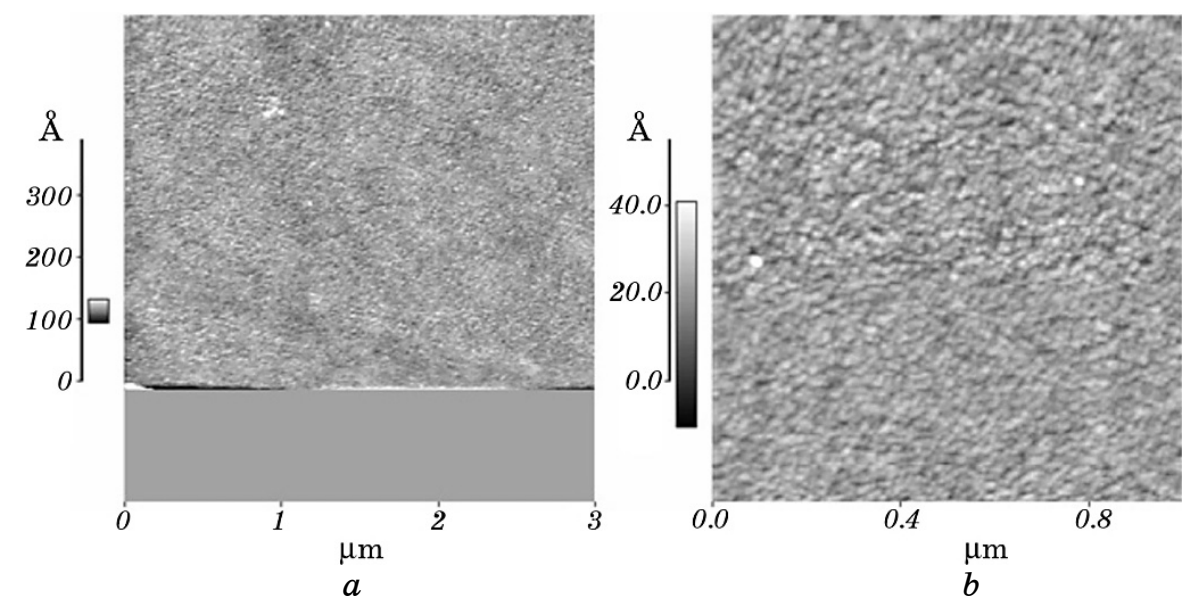

$R_{\mathrm{pv}}=4.76 \mathrm{~nm}, R_{\mathrm{ms}}=0.435 \mathrm{~nm}$
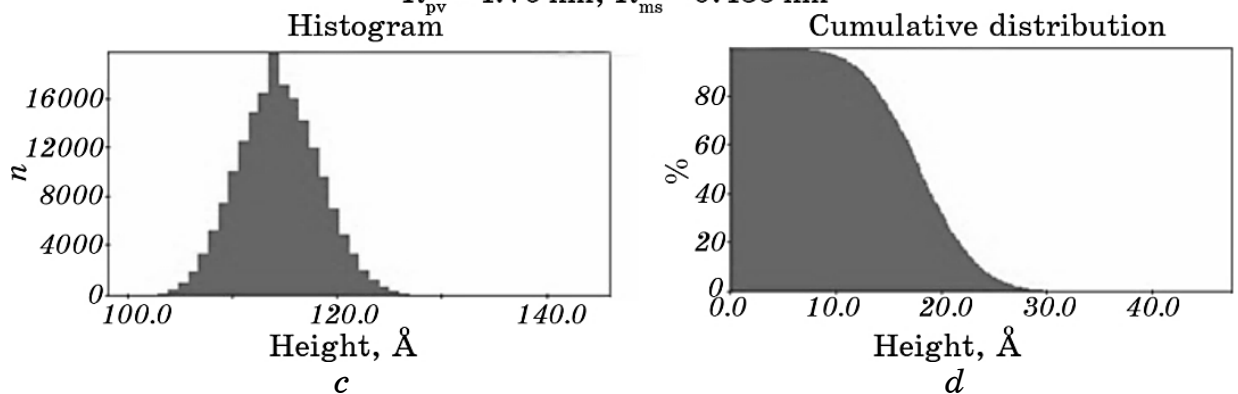

Fig. 2. Surface topography of Si-TiN-film structures obtained under cyclic exposures of ion beams with the energy of $90 \mathrm{eV}$ on the film surface. 
For the low ion energy $(10 \mathrm{eV})$, the more developed nanoscale film structure (Fig. 2) forms with the average crystallite size of $20-40 \mathrm{~nm}$. The corresponding surface roughness values are equal to $R_{\mathrm{pv}}=138 \AA$ and $R_{\mathrm{ms}}=13.5 \AA$. Formation of nanostructured relief of film's surface under these technological conditions takes place with the predominance of adsorption over desorption of atoms. The energy relaxation of surface ions goes to the nearly equilibrium conditions. Such quasiequilibrium conditions favour the structure flattening followed by approach to its uniform distribution over the surface.

For the low ion energy ( $\cong 200 \mathrm{eV}$ ) (Fig. 4), which is significantly higher than the self-sputtering threshold, the islet film structures with the average crystallite size of $100 \mathrm{~nm}$ form against the background of the nanosize structures. The corresponding surface roughness values are equal to $R_{\mathrm{pv}}=550 \AA$ and $R_{\mathrm{ms}}=50.5 \AA$. Formation of nanostructured relief of film's surface under these technological conditions takes place with substantial predominance of desorption of atoms. A far more non-equilibrium energy distribution appears in the condensate, and the ion energy is sufficient for destruction of existing
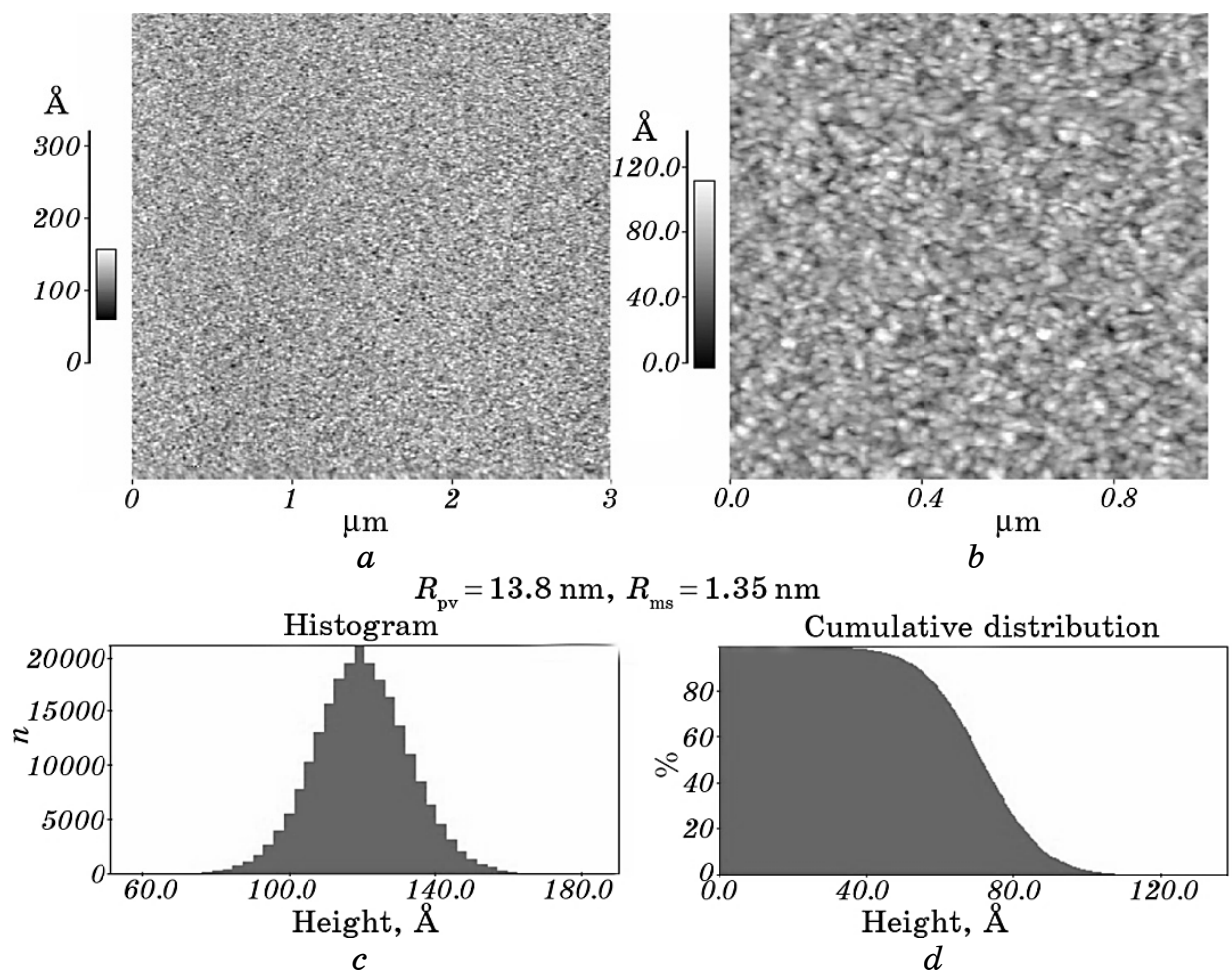

Fig. 3. Surface topography of Si-TiN-film structures obtained under cyclic exposures of ion beams with the energy of $10 \mathrm{eV}$ on the film surface. 
atomic and chemical bonds with scattering of condensate atoms. Scattering of substrate atoms is also possible.

The results of investigations obtained by scanning tunnelling microscopy (STM) are consistent with those obtained by AFM. STM micrographs (Fig. 5) show that nanostructure of iron films (Fig. 5, b) adequately reflects the morphology of the transition layer of titanium nitride (Fig. 5, a). The three-dimensional image of the resulting structure of the catalytic iron layer intended for further synthesis of CNTs is shown in Fig. 6.

Structure analysis of the films formed for the different ion energies shows the presence of the monotonous relationship between the size of nanoclusters (ranging from 5 to $100 \mathrm{~nm}$ ) and the ion energy (from 1020 to $90-100 \mathrm{eV})$.

Thus, the controlled formation of nanostructured relief in the range of $10-100 \mathrm{~nm}$ is shown to be possible and dependent on the technological conditions of formation of TiN-Fe-film heterostructures. The assisted cyclical effect of plasma fusion reactor creates such nonequilibrium condensation of atoms adsorbed on the surface that facili-
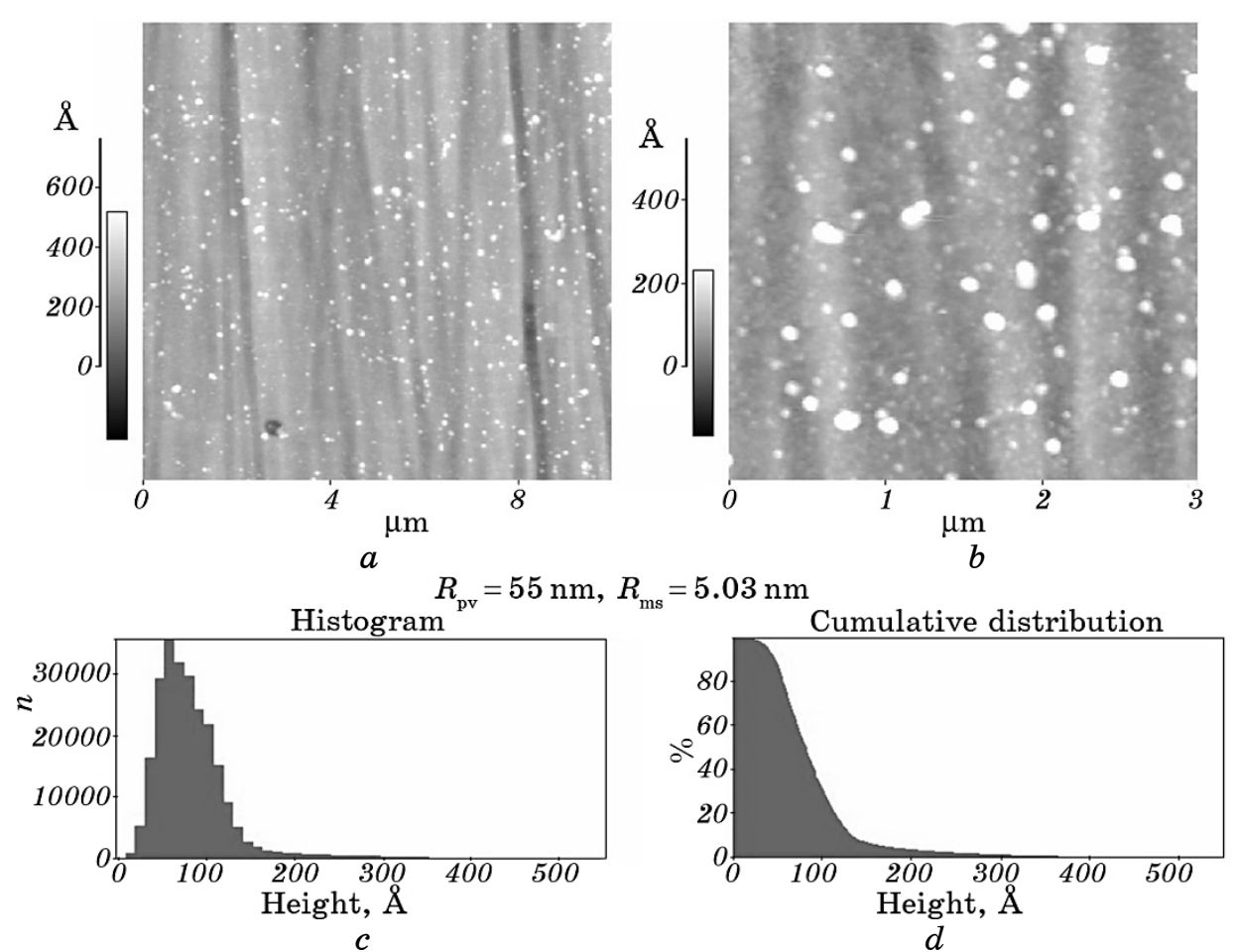

Fig. 4. Surface topography of Si-TiN-film structures obtained under cyclic exposures of ion beams with the energy of $200 \mathrm{eV}$ on the film surface. 
tates creation of the regular surface structure of nanoclusters.

The formation of nanostructured relief of films is based on competitive adsorption and desorption of atoms, and formation and destruction of existing atomic and chemical bonds with the energy relaxation
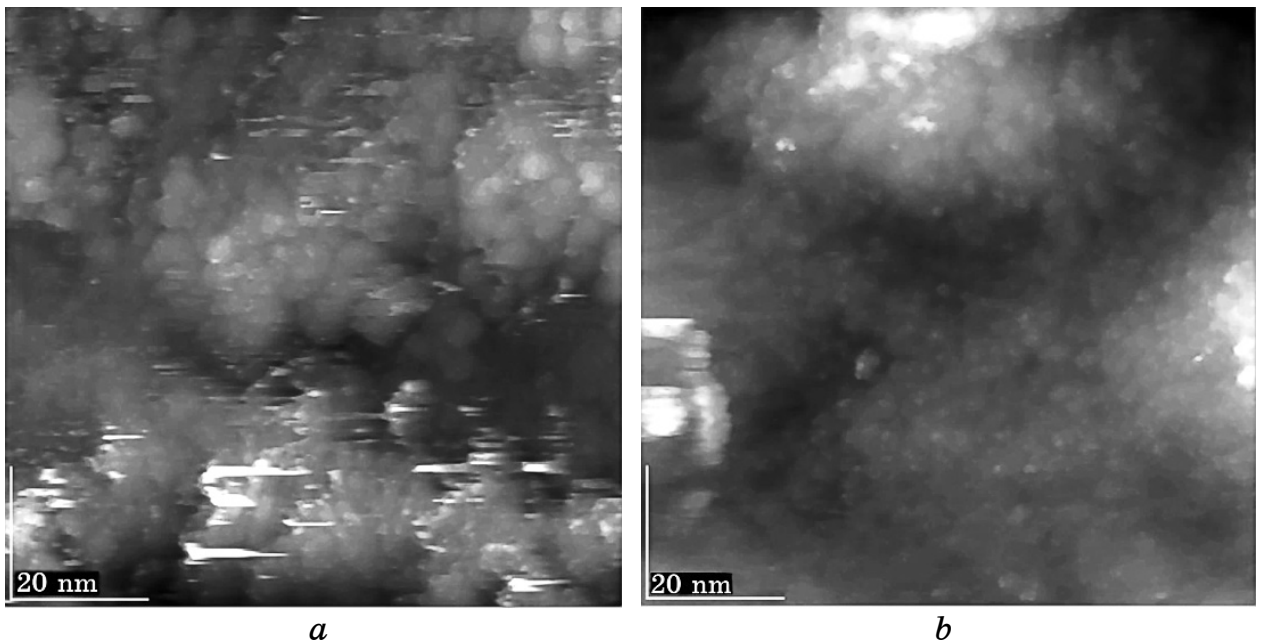

Fig. 5. Nanostructured films on (001)Si: $(a) \mathrm{TiN}$ and (b) Fe/TiN for the substrate holder potential of $90 \mathrm{~V}$.

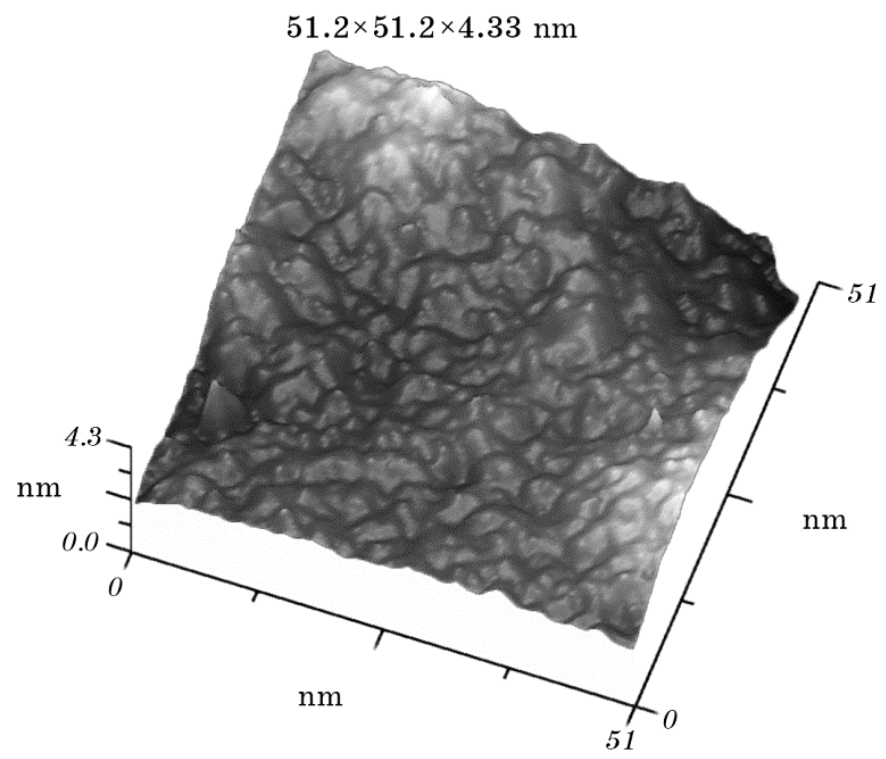

Fig. 6. Three-dimensional STM images of the resulting structures of the catalytic iron layer. 
of surface ions to the equilibrium condensate temperature. Then, the energy change of plasma flow significantly affects mechanisms of the nanoscale surface relief of the produced film structures. However, it should be noted that investigations of the combined effect of other factors (e.g., a substrate temperature, an ion flow density and a material flow density) on formation of the nanoscale surface relief on film structures are necessary for the choice of the more optimal technological parameters. AFM data indicate the possibility of controlled formation of the nanoscale surface relief on the obtained film structures.

\section{CONCLUSIONS}

Structure analysis of the films formed for the different ion energies elucidates the presence of the monotonous relationship between the nanocluster sizes (in the range of 5 to $100 \mathrm{~nm}$ ) and the ion-flow energy (in the range from 10-20 to $90-100 \mathrm{eV}$ ). The controlled formation of the nanostructured relief with the roughness in the range of 10$100 \mathrm{~nm}$ is shown to be possible and dependent on the technological conditions of formation of TiN-Fe-film heterostructures. The assisted cyclical effect of the plasma fusion reactor creates such nonequilibrium condensation of atoms adsorbed on the surface that facilitates creation of the regular surface structure of nanoclusters. The formation of nanostructured relief of films is based on competitive adsorption and desorption of atoms, and formation and destruction of existing atomic and chemical bonds with the energy relaxation of surface ions to the equilibrium condensate temperature. Then, the energy change of plasma flow significantly affects the mechanisms of the nanoscale surface relief of the obtained film structures. However, it should be noted that investigations of the combined effect of other factors (the substrate temperature and the material flow density) on formation of the nanoscale surface relief on the film structures are necessary for the choice of the more optimal technological parameters.

\section{REFERENCES}

1. Carbon Nanotube Electronics (Eds. A. Javey and J. Kong) (New York: Springer: 2009).

2. Carbon Nanotubes and Related Structures: Synthesis, Characterization, Functionalization, and Applications (Eds. D. M. Guldi and N. Martín) (Weinheim, Germany: Wiley-VCH: 2010).

3. M. Meyyappan, L. Delzeit, A. Cassell, and D. Hash, Plasma Sources Sci. Technol., 12: 205 (2003).

4. A. V. Melechko, V. I. Merkulov, T. E. McKnight, M. A. Guillorn, K. L. Klein, D. H. Lowndes, and M. L. Simpson, J.Appl. Phys., 97: 041301 (2005).

5. M. S. Bell, K. B. K. Teo, and W. I. Milne, J. Phys. D: Appl. Phys., 40: 2285 
(2007).

6. M. E. Svavilnyj, Metallofiz. Noveishie Tekhnol., 32, No. 11: 1485 (2010) (in Russian).

7. J. I. Sohn, Ch.-J. Choi, S. Lee, and T.-Ye. Seong, Appl. Phys. Lett., 78: 3130 (2001).

8. V. F. Semenyuk, Eh. M. Rudenko, I. V. Korotash, L. S. Osipov, D. Yu. Polotskiy, K. P. Shamray, V. V. Odinokov, G. Ya. Pavlov, and V. A. Sologub, Metallofiz. Noveishie Tekhnol., 33, No. 2: 223 (2011) (in Russian). 